\title{
Build, buy, or rent? A systems view of faculty design work in the digital learning era
}

\author{
Laura Lohman ${ }^{1}$ (D) \\ Accepted: 10 November 2020 / Published online: 20 November 2020 \\ (c) Association for Educational Communications and Technology 2020
}

\begin{abstract}
To suggest sound practices in obtaining the faculty design talent needed to rapidly deploy or scale up digital learning, this paper adopts a systems view of the findings and implications of "The Process of Designing for Learning: Understanding University Teachers' Design Work" by Bennett et al. (Educational Technology Research and Development 65(1), 125-145, 2017). Bennett et al.'s article makes an important contribution to our growing understanding of faculty capacity for and approaches to course design. Their work establishes faculty roles as designers, which is an essential consideration as institutions seek digital design talent. Nevertheless, important limitations of their research are limited detail about faculty design skills and an emphasis on how faculty design resembles others' design approaches. This paper suggests specific ways that institutions can apply and extend insights from Bennett et al.'s research to cultivate faculty design talents in nimble responses to large-scale or rapid shifts to digital learning through practices of professional development and strategic faculty hiring.
\end{abstract}

Keywords Course design · Instructional design · Faculty development · Faculty hiring · Systems thinking

Bennett et al.'s (2017) research on faculty design offers valuable insights for universities seeking digital design talent. Faculty design was questioned when Oblinger and Hawkins (2006) asked if institutions should spend costly faculty assets on responsibilities for which faculty were untrained, including instructional design. Many universities responded accordingly to the COVID-19 pandemic, hiring or contracting instructional designers in buy and rent approaches to a talent gap. Others used professional development to build internal faculty design talent. Bennett et al.'s findings have important implications for such institutional talent questions amid digital learning; to highlight them, this paper uses a systems-thinking perspective that views human resources processes as fundamental mechanisms to improve course quality and design (Lohman 2020c). Rather than discounting faculty ability to tackle digital design, institutions can apply and extend insights from Bennett

Laura Lohman

lohmanl@queens.edu

1 Queens University of Charlotte, 1900 Selwyn Ave, MSC 1383, Charlotte, NC 28274, USA 
et al.'s research to cultivate faculty design talent for digital learning through practices of professional development and strategic faculty hiring.

\section{Summary}

Bennett et al. establish that faculty are not merely subject matter experts but rather learning professionals capable of designing, developing, and delivering courses thoughtfully. Describing iterative faculty design efforts as "possibly never truly complete" (2017, p. 138), they underscore design's prevalence in faculty work and complement other portrayals of faculty roles in course design (Drysdale 2019). Unlike Baldwin et al.'s (2018) informal design process model, their interviews reveal faculty designing continuously and reflectively. Faculty practices of iteration, designing during delivery, and using delivery to improve design, which Bennett et al. document, can be leveraged in digital delivery and agile design.

\section{Limitations}

To do so, limitations of Bennett et al.'s approach must be overcome. One is limited detail regarding faculty use of specific design skills. Due to the timing, design, and broad scope of their interview process, many skills remain unspecified in the "initial stage" and "design activities" of their descriptive model of faculty design. Important for build, buy, and rent approaches is an understanding that faculty can learn and apply specific instructional design skills, including learner analysis, context analysis, and subordinate or component skills analysis (Lohman 2019). More timely and focused interviews can clarify this faculty capacity. For example, a research participant interviewed by this author shortly after professional development elaborated their intention of addressing the implications of an entry skills line for learners: "I think where is that line where I expect them to know [things already]? And what am I going to do about people who fall below that line? And how am I going to figure out who falls below that line?" A second limitation is Bennett et al.'s emphasis on how faculty design resembles other design approaches. As delineated through the following suggestions, differences in faculty design work must also be recognized to strengthen faculty design talent.

\section{Suggestions for building faculty design talent}

Several practical suggestions developed from points in Bennett et al.'s work will assist institutions in building internal faculty design talent for digital learning. First, Bennett et al. noted the importance of design tools that "connect with teachers' existing practices" (2017, p. 126). However, making this connection requires recognizing how faculty design differs from that of other designers. Suggestions for noting differences include asking open-ended questions of faculty developers and teaching-focused faculty to understand what design concepts, terms, techniques, and sources faculty use. These may include institution- and discipline-specific resources, as seen in the work of Goldacre et al. (2013) and Lo (2010).

Second, rather than being limited, as Bennett et al. noted, tools supporting faculty design may exist elsewhere or be termed differently. A suggestion for locating existing tools is 
inquiring about faculty developers' course design institutes, which often stress backwards design and use different design texts (Lohman 2019; Bach et al. 2016; Palmer et al. 2016). More specifically, exploring concepts like Fink's (2013) taxonomy of significant learning can clarify how faculty select and word learning outcomes and can foster cross-stakeholder dialogue to inform working relationships and large-scale interventions, including professional development (Lohman 2020c; Chen and Carliner 2020).

Third, Bennett et al. noted faculty colleagues as resources with valuable input capable of supporting faculty design. Institutions should leverage specific faculty roles accordingly. Faculty leaders of academic units and programs can organize debriefs of lessons learned and foster consensus around disciplinarily suitable approaches to digital design, as illustrated in Laster's (2010) work. Full-time contract faculty hired as committed teaching specialists can be cultivated as design resources in inclusive academic environments and work with colleagues to mitigate their challenges of varied responsibilities noted by Bennett et al.

Finally, when adopting a build approach, the impact of reflective faculty practices captured in Bennett et al.'s account can be maximized by thoughtfully shaping faculty experiences as learners. Institutions should offer professional development that models and provides effective digital learning experiences for faculty. Suggestions include delivering the professional development in the same modality as anticipated instruction, providing faculty opportunities for asynchronous and synchronous interaction, and prompting faculty to reflect on their experiences as digital learners in professional development to inform their design work (Lohman 2020a).

\section{Suggestions for buying or renting faculty design talent}

Bennett et al.'s research can also inform long-term and contract faculty hiring, as it begins to break down design, development, and delivery work often conceptualized generally as "teaching" in hiring. Systematic prioritization of skills needed for this work is important given the costs of unbundled faculty models for course design, development, and delivery (Neely and Tucker 2010). Despite the limited detail in Bennett et al.'s model, futureoriented, strategic job analysis can be used to systematically identify and prioritize faculty design skills for supporting digital learning and shape selection processes accordingly (Lohman 2020b). Strategically designed selection can identify candidates whose design work is informed by valuable contemporary experiences, such as pedagogical training and online learning.

With strategic faculty hiring, professional development, or both, institutions can gain faculty talent needed for large-scale or rapid shifts to digital learning. When facing the build, buy, or rent dilemma, institutions should consider carefully the insights and implications of Bennett et al.'s research for faculty design.

\section{Compliance with ethical standards}

Conflict of interest The author declares no conflict of interest.

Ethical approval Compliance with standards of research involving humans and subjects: All procedures performed in studies involving human participants were in accordance with the ethical standards of the institutional research committee and with the 1964 Helsinki Declaration and its later amendments or comparable ethical standards. 
Informed consent Informed consent was obtained from all individual participants involved in the study.

\section{References}

Bach, D. J., Weiß, P., Inkelas, K. K., \& Riewerts, K. (2016). Introducing and assessing learning-focused course design at the University of Virginia, USA and at Bielefeld University, Germany. Die Hochschullehre, 2, 1-19.

Baldwin, S. J., Ching, Y.-H., \& Friesen, N. (2018). Online course design and development among college and university instructors: An analysis using grounded theory. Online Learning, 22(2), 157-171. https ://doi.org/10.24059/olj.v22i2.1212.

Bennett, S., Agostinho, S., \& Lockyer, L. (2017). The process of designing for learning: Understanding university teachers' design work. Educational Technology Research and Development, 65(1), 125-145. https://doi.org/10.1007/s11423-016-9469-y.

Chen, Y., \& Carliner, S. (2020). A special SME: An integrative literature review of the relationship between instructional designers and faculty in the design of online courses for higher education. Performance Improvement Quarterly (Early View). https://doi.org/10.1002/piq.21339.

Drysdale, J. T. (2019). The collaborative mapping model: Relationship-centered design for higher education. Online Learning, 23(3), 56-71. https://doi.org/10.24059/olj.v23i3.2058.

Fink, L. D. (2013). Creating significant learning experiences: An integrated approach to designing college courses. New York: Wiley.

Goldacre, L., Bolt, S., \& Lambiris, M. (2013). Designed for learning: A case study in rethinking teaching and learning for a large first year class. Journal of the Scholarship of Teaching and Learning, 13(1), 24-44.

Laster, S. (2010). Model-driven design: Systematically building integrated blended learning experiences. Journal of Asynchronous Learning Networks, 14(1), 39-53. https://doi.org/10.24059/olj.v14i1.1637.

Lo, C. (2010). Using a SoTL approach in designing and teaching a graduate seminar course. International Journal for the Scholarship of Teaching and Learning, 4(1), 1-7. https://doi.org/10.20429/ijsot 1.2010 .040115 .

Lohman, L. (2019). Significant, backwards, and systematic: An integrated approach to course design. In $42^{\text {nd }}$ Annual Proceedings of the International Convention of the Association for Educational Communications and Technology (Vol. 2, pp. 390-398).

Lohman, L. (2020a). Leveraging sociomaterial practices to build elearning literacy in "suddenly online" professional development. Journal of Literacy and Technology, 21(3), 59-81.

Lohman, L. (2020b). Strategic hiring: Using job analysis to effectively select online faculty. Online Journal of Distance Learning Administration, 23(3). Retrieved from https://www.westga.edu/ distance/ojdla/ fall233/lohman233.html

Lohman, L. (2020c). Using soft systems thinking to craft instructional design and technology interventions. TechTrends, 64(5), 720-729. https://doi.org/10.1007/s11528-020-00536-x.

Neely, P. W., \& Tucker, J. P. (2010). Unbundling faculty roles in online distance education programs. International Review of Research in Open and Distance Learning, 11(2), 20-32.

Oblinger, D. G., \& Hawkins, B. L. (2006). The myth about online course development. EDUCAUSE Review, $41,14-15$.

Palmer, M. S., Streifer, A. C., \& Williams-Duncan, S. (2016). Systematic assessment of a high-impact course design institute. To Improve the Academy, 35, 339-361.

Publisher's Note Springer Nature remains neutral with regard to jurisdictional claims in published maps and institutional affiliations.

Laura Lohman is Director of the Center for the Advancement of Faculty Excellence at Queens University of Charlotte. She is a certified Project Management Professional and Human Resources Senior Certified Professional with 15 years of experience applying instructional design principles to university teaching and workplace learning. 